\title{
Plate motions, Andean orogeny, and volcanism above the South Atlantic convection cell
}

\author{
Laurent Husson $\left(1,2,{ }^{*}\right)$, Clinton P. Conrad (3), and Claudio
}

Faccenna (4)

\author{
${ }^{1}$ CNRS UMR 6118, Géosciences Rennes, Université Rennes 1, France \\ (laurent.husson@univ-rennes1.fr) \\ ${ }^{2}$ CNRS UMR 6112, Laboratoire de Planétologie et Géodynamique de Nantes, \\ France \\ ${ }^{3}$ Department of Geology and Geophysics, SOEST, University of Hawaii, \\ Honolulu, HI 96822, USA (clintc@ hawaii.edu) \\ ${ }^{4}$ Dipartimento di Scienze Geologiche, Universita Roma Tre, Rome, Italy \\ ( $\underline{\text { faccenna@uniroma3.it) }}$
}

\begin{abstract}
:
The geometric and kinematic evolution of the Andes provides insight onto the nature of the force balance beneath the South American plate. While the Andean load is opposed on its western edge by the force induced by subduction of the Nazca plate, its more elusive eastern counterpart, which we explore herein, requires some contribution from the mantle beneath the South Atlantic. Using a mantle flow model, we show that the Andes owe their existence to basal drag beneath South America caused by a cylindrical convection cell under the South Atlantic. We find that the observed Andean uplift requires both westward push from active upwelling beneath Africa and westward drag toward the downgoing Nazca slab. These mutuallyreinforcing downwellings and upwellings amount to $38 \%$ and $23 \%$ of the total driving force, respectively. Further decomposition reveals that the South Atlantic cell is most vigorous near its center, rendering the net drag force higher where the Andes also
\end{abstract}


reach their highest elevation. Kinematic reconstructions suggest that the South Atlantic cell could have grown owing to the migration of the Nazca slab until $\sim 50$ Ma. We propose that from 50 Ma onwards, the cell may have ceased growing westward because (i) it had reached an optimal aspect ratio and (ii) the Nazca slab became anchored into the lower mantle. Continued westward motion of the plates, however, moved the surface expressions of spreading and convergence away from the upwelling and downwelling arms of this cell. Evidence for this scenario comes from the coeval tectonic, morphologic, and magmatic events in Africa and South America during the Tertiary.

Keywords : Andes, Atlantic, Africa, subduction, upwellings, mantle flow, orogenesis

\section{1) Introduction}

The vast majority of subduction models indicate that isolated subduction systems naturally tend to retreat, i.e. their trenches migrate toward the foreland, the unsubducted part of the downgoing lithosphere (e.g., Garfunkel et al., 1986; Funiciello et al., 2003). This setting naturally favors back-arc extension and is thus almost by definition not prone to mountain building, unless far field forces cause the upper plate or subducting plate to move toward the subduction zone faster than the trench retreats. With the particular example of the Nazca subduction zone beneath South America (Russo and Silver, 1996; Silver et al., 1998), it has become clear that upper plate dynamics play a key role in orogenesis: South America is driven to the West faster than the trench retreats, which leads to edification of the Andes (e.g., Ruff and Kanamori, 1980; Conrad et al., 2004). However, the reasons that some upper plates are capable of advancing toward trenches remain unclear. Since the Cretaceous, the westward drift of the Americas has been opposed from the west by the adjacent plates in the Pacific basin, as revealed by the American Cordilleras. The load of these orogenies exerts a force that is comparable in magnitude to plate tectonic driving forces and opposes the westward override of the American plates above the NazcaFarallon plates. For South America, this in turn means that a westward force, applied to the South American plate, suffices to overcome the orogenic resistance. 
Tectonic forces balance everywhere on Earth and this naturally includes the Nazca trench and the Andean belt. As a result, mountain belts, and more generally backarc regions (Lallemand et al., 2008), can be regarded as dynamometers: their geometry and kinematics provide a straightforward tool to measure the force balance at their location. The Andes (Fig. 1a) stand above $5000 \mathrm{~m}$ and nevertheless continue to deform only because tectonic forces are strong enough to allow them to do so. For the Andes, these forces must amount to $\sim 810^{12} \mathrm{~N} \mathrm{~m}^{-1}$ on average (Husson and Ricard, 2004, Iaffaldano and Bunge, 2006). This force includes a buoyancy component (sometimes referred to as gravitational potential energy) associated with the tendency of locally thickened crust to spread under its own weight, and a viscous component associated with dissipation in the deforming crust. To the west, this force is balanced by the convergence with the Nazca slab, and could manifest as interplate coupling at the plate interface (Van Hunen et al,. 2003; Husson and Ricard, 2004; Iaffaldano and Bunge, 2006; Meade and Conrad, 2008) or viscous dissipation in the deforming Nazca slab, surrounding mantle, and entire Pacific mantle reservoir (Husson et al., 2008). More intriguing, however, is the eastern side, where the elevation of the Andes must be balanced by forces associated with driving forces on the South American plate. Candidates are few, and chiefly include ridge push and basal tractions associated with drag of mantle flow on the base of the South American plate. Literal formulation of ridge push (e.g., Turcotte and Schubert, 1982) in the South Atlantic indicates that this force may amount to a maximum of $\sim 410^{12} \mathrm{~N} \mathrm{~m}^{-1}$, which we conservatively consider as a maximum value, although others suggest that it may be closer to $\sim 310^{12} \mathrm{~N} \mathrm{~m}^{-1}$ (Parsons and Richter, 1980; Richardson, 1992). Ridge push therefore at most amounts to only half the force needed to support the growing Andean belt. The remaining source $\left(\sim 410^{12} \mathrm{~N} \mathrm{~m}^{-1}\right)$ must therefore arise from active basal drag beneath the South American plate.

We argue that basal drag is intimately related to the dynamics of the South Atlantic basin since its opening at $~ 130$ Ma (e.g., Torsvik et al., 2009). Subsequent spreading resulted from westward migration of South America towards the retreating Nazca subduction zone and from northeastward migration of Africa towards the Tethyan subduction zone. Africa gradually collided with Eurasia during the Tertiary, which prevented further significant convergence of Africa towards Eurasia (Jolivet 
and Faccenna, 2000). The Atlantic continued to spread by expelling South America to the west more efficiently, which lead to contraction in South America and ultimately contributed to the formation of the Andes during the Cenozoic (Silver et al., 1998). Contemporary and widespread tectono-metamorphic events occurred in the African counterpart (Burke, 1996). By combining a mantle flow model with a review of the geological record, we herein constrain the nature of mantle flow beneath the South Atlantic, and apply it to the dynamics of Andean orogenesis. This protocol is designed to test whether a plausible set of parameters that characterize mantle flow can balance the orogenic load of the Andes.

\section{2) Force balance on the South American plate}

In order to investigate whether basal shear from the convecting mantle is powerful enough to balance the force budget, we need to quantify both mantle flow and shear tractions beneath the South Atlantic. On the western side, the Andean load is balanced at the plate boundary by interplate coupling and viscous forces in the deforming Nazca slab and Pacific mantle reservoir (Husson et al., 2008). The eastern counterpart is more elusive and requires a careful analysis of convection in the South Atlantic domain. We build upon the earlier global mantle flow models of Conrad and Behn (2010) and Naliboff et al. (2009), which use the finite element code CitcomS (Zhong et al., 2000; Tan et al., 2006). We use a linear combination of an internallydriven convection model (mantle driven) and a plate-driven flow model (see full description in Conrad and Behn, 2010). The addition of each resulting flow is rendered possible by the assumption of a Newtonian -though spatially variablerheology.

The first model is density-driven, wherein mantle flow is excited by mantle density heterogeneities as inferred from seismic tomography (S20RTSb, Ritsema et al., 2004), by converting the seismic velocity structure below $300 \mathrm{~km}$ into a density structure using a conversion factor set to $0.15 \mathrm{~g} \mathrm{~cm}^{-3} \mathrm{~km}^{-1} \mathrm{~s}$, as in the earlier models of Conrad and Behn (2010), after Karato and Karki (2001). This conversion is done under the arguable assumption that all anomalies are thermal, as opposed to chemical, in origin (see section 3.3). Within the shallowest $300 \mathrm{~km}$, we follow previous studies 
(e.g., Conrad \& Behn, 2010) by setting density anomalies to null because the straightforward conversion from seismic tomography to density notoriously breaks down at those depths. This density driven model is subsequently scaled by a factor $\gamma$ that allows for the uncertainty in the conversion factor. Our model is instantaneous and buoyancy-driven, and thus does not attempt to resolve the mantle's temporal or thermal development. Surface conditions are no slip, meaning that the flowing mantle shears beneath a rigid outer shell. Free slip is imposed at the core-mantle boundary. We assign mantle viscosities following Conrad and Behn (2010), who employ a uniform viscosity lower mantle (below $670 \mathrm{~km}$ ), an asthenosphere (above $300 \mathrm{~km}$ and below the lithospheric base), and a lithosphere, with reference viscosities that are 50, 0.1 , and up to 1000 times the $\eta_{u m}=10^{21} \mathrm{~Pa} \cdot \mathrm{s}$ reference viscosity of the upper mantle (300-670 km), prior to scaling by a factor $\beta$ as described below. Also following Conrad and Behn [2010], the low-viscosity asthenosphere smoothly transitions into high viscosity lithosphere, which has a variable thickness that is consistent with seafloor age (for oceans) or near-surface tomography (for continents). These models give predictions of the driving component of the shear traction field beneath the lithosphere as a function of $\gamma$.

In principle, the density-driven flow field, if acting beneath mobile surface plates, should drive those plates in the directions that we observe them to move (e.g., Ricard \& Vigny, 1989; Gable et al. 1991). However, the coupling between plate motions, plate boundary forces, and mantle flow (and the implementation of these couplings within a mantle flow model) remains a topic of active research (e.g., Stadler et al., 2010). Because predicting the observed motion of South America from a fully dynamic model is beyond the scope of this study, we instead impose plate motions (in the no-net-rotation (NNR) reference fame, NUVEL-1A NNR; DeMets et al., 1994) as a surface velocity boundary condition and compute flow in the underlying passive viscous mantle after removing density heterogeneity. Because we employ the same viscosity structure that we used to compute the density-driven flow field, and also utilize boundary conditions of the same type (free slip on the CMB and imposed velocities on the surface), we can sum these two flow fields (e.g., Hager \& O'Connell, 1981; Ricard \& Vigny, 1989) and compute basal tractions induced by flow driven by the combination of mantle density heterogeneity and relative plate motions. 
In the absence of lateral viscosity heterogeneity, convection in the Earth's mantle is inherently poloidal and therefore should induce no net torques on the lithosphere and no net rotation of the lithosphere relative to the deep mantle (Solomon and Sleep, 1974). However, slabs, cratons and plate boundaries introduce abundant lateral viscosity heterogeneity to the upper mantle, and can cause net motion of the lithospheric shell with respect to the lower mantle (Ricard et al., 1991; Zhong, 2001; Becker, 2006). Most constraints on net lithosphere motion relative to hotspot reference frames suggest that the lithosphere drifts slowly in a direction that roughly parallels that of the Pacific plate (pole given in Table 1) (Becker \& Faccenna, 2009), but with an uncertain amplitude that ranges between zero (NNR frame; DeMets et al., [1994]) and 0.44\% Myr (HS3 frame; Gripp and Gordon, 2003). Like the relative plate motions, this net motion of the lithosphere is also resisted by mantle drag that contributes to the force balance on plates. Therefore, we calculate tractions associated with a variable amount of net lithosphere rotation (as described below), and include them in the force balance for the South American plate.

Although we impose a no-net-rotation surface condition for both our densitydriven and plate-driven flow models, lateral viscosity variations in these models can induce a component of degree-1 net rotation at depth. In fact, we detected a net rotation on $\mathrm{CMB}$ for both flow fields (Table 1) that is directed roughly opposite to the expected net rotation for surface motions (the poles for plate-driven and densitydriven flows are $66.6^{\circ}$ and $10.6^{\circ}$ separated from the HS3 pole, respectively, with an opposite rotation sense). Thus, if we utilize no-net-rotation on the CMB as our reference frame, then both the density-driven and plate-driven flow fields already include some net rotation, roughly parallel to net rotation, with amplitudes that are $2.1 \%$ and $5.0 \%$ of the HS3 net rotation amplitude (Table 1). Because the amplitude of the density-driven flow field scales linearly with $\gamma$ and inversely with $\beta$, we can write $\alpha_{\text {ref }}$, the total net lithosphere rotation (relative to a non-rotating CMB and as a fraction of the HS3 amplitude) associated with the combined plate-driven and density-driven flow fields, as:

$$
r_{\text {ref }}=0.021+0.05 /
$$


Because the plate motions in our models are kinematically-constrained, they do not incorporate all of the physics associated with plate motions and mantle flow. Thus, the net rotation that we associate with these models, described by equation (1), may not be consistent with the actual net rotation of the Earth's lithosphere, which may be driven partly by forces that are not included in our models. As a result, and because there is some uncertainty in the amplitude of the observed net rotation, but not so much on the pole location (e.g., Becker \& Faccenna, 2009), we introduce an additional variable component of net rotation on the system. To compute this last component, we follow Conrad and Behn (2010) by imposing surface velocity boundary conditions consistent with the net rotation component of the lithosphere, that we define from the HS3 plate motion model (Table 1; Gripp and Gordon, 2003). To prevent solid body rotation of the mantle, which is unphysical, we apply a rigid boundary condition at the CMB, also following Conrad and Behn (2010). These conditions induce shear deformation that is distributed within the various viscous layers of the mantle, and allow us to estimate the shear tractions that are associated with any net rotation of the lithosphere that is faster than $\alpha_{\text {ref. }}$. We scale these additional tractions by a variable fraction $\alpha_{i m p}$, measured relative to the HS3 amplitude. Because the net rotation poles for the density-driven, plate-driven and netrotation-driven fields are approximately aligned (Table 1), we can combine their amplitudes linearly so that the total net rotation on the system $\alpha_{t o t}$ is given by:

$$
\alpha_{t o t}=\alpha_{r e f}+\alpha_{i m p}
$$

Each component of the flow field (density-driven, plate-driven, and netrotation-driven) yields a field of shear stresses beneath the lithosphere. The sum of the three sub-components gives a prediction of the resistive shear traction at the base of the lithosphere. Traction magnitudes associated with the density-driven flow field scale with the density scaling factor $\gamma$, while those associated with plate-driven flow (both NNR and net-rotation components) scale with the viscosity of the sublithospheric mantle, which we set to a factor $\beta$ of the above-described reference viscosity structure (as in Conrad and Behn, 2010). Note that combining the NNR plate-driven flow field (which utilizes a stress-free CMB) with the imposed netrotation flow field (which includes a fixed $\mathrm{CMB}$ ) is not strictly permitted because of the different CMB boundary conditions utilized by these models. Therefore, we 
emphasize that the tractions associated imposed net rotation (with an amplitude that scales with $\alpha_{\mathrm{imp}}$ ) are merely an estimate of the tractions that may be missing from our flow models but should be present in the Earth if the actual net rotation is faster than $\alpha_{\text {ref. }}$

The net shear traction $\tau$ underneath the lithosphere is predicted by the sum of contributions from the density-driven, plate-driven, and net-rotation-driven models. It then writes

$$
={ }_{\mathrm{int}}+\left({ }_{n n r}+{ }_{i m p h s}\right),
$$

where $\tau_{\text {int }}$ is the internally driven shear, $\tau_{\mathrm{nnr}}$ is the shear stress due to the relative plate motions and $\tau_{\mathrm{hs} 3}$ is the shear stress due to the imposed net rotation of the lithosphere. Of course, our model results are subject to uncertainties that not only result from the above assumptions but also from the resolution of the seismic tomography model input, although the values for $\alpha_{\mathrm{imp}}, \beta$, and $\gamma$ account for this to an unknown extent.

To estimate the westward-directed forces that mantle flow exerts on the South American plate, we first computed the total torque $T_{s}$ exerted by the internally driven shear tractions beneath the South American plate. This simply writes $T_{s}=\underset{\text { sam }}{r} \quad{ }_{\text {int }} d s$, where $\boldsymbol{r}$ is the radial unit vector, $\tau_{\text {int }}$ is the local shear stress, and sam is the area of the South American plate. This yields a pole of rotation located at $\left(10^{\circ} \mathrm{E}\right.$, $\left.64^{\circ} \mathrm{S}\right)$. To express the geographical distribution of these tractions, we then projected the local net shear traction vectors along the small circles that circumscribe that Euler pole (Fig. 1b) and integrated them from the ridge to the trench beneath the South American plate. This yields a force per unit trench length, and recognizes that tractions oriented perpendicular to these small circles are balanced internally and do not help to support the Andean load. The average force balance along the trench therefore writes

$$
\frac{1}{L_{L}} F_{o} d l=\frac{1}{L_{L}}{ }^{t} d x d l+\bar{F}_{r p},
$$

where $L$ is the length of the Nazca trench (total is $8000 \mathrm{~km}$ ) and $F_{o}$ denotes the force locally exerted by the Andean orogen (set to $8 \times 10^{12} \mathrm{~N} \mathrm{~m}^{-1}$ on average). The first term on the right hand side is the total shear traction that drags South America towards the 
trench (from the ridge $r$ to the trench $t$ ) and $\bar{F}_{r p}$ is the mean ridge push (set to $4 \times 10^{12}$ $\mathrm{N} \mathrm{m}^{-1}$ ). Technically, basal shear is set to null in areas undergoing deformation (as defined in Kreemer et al., 2003), in order to exclude the traction right below the Andes (because the traction beneath the Andes is dominated by the Nazca plate, not by the mantle beneath the South American plate). In order to explore the field of plausible combinations of $\alpha_{\mathrm{imp}}, \beta$, and $\gamma$, we solved for $\beta$ from equation (4) for a range of values for $\alpha_{\mathrm{imp}}$ and $\gamma$. Computing basal drag shows that the force balance can be achieved using values of $\alpha_{\text {imp }}, \beta$ and $\gamma$ that correspond to standard values for the sublithospheric viscosity ( $\beta=0.5$ corresponding to $\eta_{U M}=5 \times 10^{20} \mathrm{~Pa} \mathrm{~s}$ ), seismic velocity to density conversion factor $(\gamma=1.13$, corresponding to a conversion factor from seismic velocity anomalies to density anomalies of $0.17 \mathrm{~g} \mathrm{~cm}^{-3} \mathrm{~km}^{-1} \mathrm{~s}$ ) and net rotation ( $\alpha_{\mathrm{imp}}=0.2$, which corresponds to $\alpha_{\mathrm{tot}}=0.33$ times the HS3 net rotation), respectively. These parameters set the reference model that we use in the following. Results are shown in Figure 2a, which in turns also indicates that the solution is non unique: we define a favorite model for the above-given values and a most plausible domain for $0.1<\alpha_{\mathrm{tot}}<0.5$ (where most Net Rotation models - besides the fast spinning HS3-fall, see e.g. Becker et al., 2006, or Conrad and Behn, 2010), $0.25<\beta<1$ (corresponding to upper mantle viscosity of $2.5 \times 10^{20} \mathrm{~Pa} \mathrm{~s}<\eta_{U M}<10^{21} \mathrm{~Pa} \mathrm{~s}$ ) and $0.67<\gamma<1.67$ (corresponding to a conversion factor between 0.1 and 0.25, after Conrad and Behn, 2010, who set it to $0.15 \mathrm{~g} \mathrm{~cm}^{-3} \mathrm{~km}^{-1} \mathrm{~s}$ ). The force balance can thus be achieved for a variety of combinations of acceptable values. Above all, this result shows that basal drag from mantle flow underneath the Atlantic easily supplies the force required to balance the Andes.

\section{3) Mantle and lithosphere dynamics in the South}

\section{Atlantic}

3.1 Mantle flow patterns beneath the South Atlantic

The net shear stresses beneath the lithosphere amount to a maximum of $4 \mathrm{MPa}$ (Fig. 1b). Below South America, their directions are well-aligned with the small circles associated with the Euler pole for the total driving torque of asthenospheric 
shear. This result implies that the direction of plate motion and underlying mantle flow are collinear, as we would expect if South America's motion is driven primarily by basal shear tractions. From visual inspection, our model seems to fit at best the fast axes of seismic anisotropy underneath South America (Fig. 1a, Asumpçao et al., 2011), which at least reveals the compatibility of our model with evidence of mantle flow.

The prominent geometric feature that arises from the mantle flow / plates model is a convection cell fed by the downgoing Nazca slab on one hand and the upwelling African superplume on the other: traction vectors (Fig. 1b) point away from Africa and towards the Nazca trench. Cross sections (Fig. 3) show that the Nazca slab drives the downwelling, while the upwelling emerges at the surface along both the western coast of Africa and the East African rift. This dual-armed upwelling beneath the two sides of Africa has been observed by several authors (e.g., Davaille et al., 2005; Forte et al., 2010; Androvandi et al., 2011). In the lower mantle, these two arms possibly merge and stem from the African superplume. Here, we define the African superplume as the elongate low-velocity structure that persists in most tomographic models, and that lies above the CMB and beneath Africa, from Cape Verde to South Africa and towards the Indian Ocean (comparable to the "banana-shaped" structure of Davaillle et al., 2005).

\subsection{Divergence of the basal shear stress field:}

The shear stress field beneath the lithosphere shows the input of the underlying flow on lithosphere deformation. As such, mapping the divergence of the horizontal stress field indicates areas undergoing compressive (negative divergence) and extensive (positive divergence) stresses due to the underlying mantle flow. In an incompressible media, that value is a measure of the vertical strain, and therefore is an indicator of the vigor of the underlying vertical flow field. In order to emphasize the most robust features, we normalized the horizontal stress tensor before computing the divergence. This delineates, in an absolute reference frame, locations where vertical currents in the mantle are strong enough to shape the geometry of the convection cells. In other words, it reveals where the flow field splits. 
The expression of the convection cell beneath the South Atlantic lithosphere (Fig. 4) is dominated by a strip of negative divergence above the Nazca-Farallon slab, on the west and by a strip of positive divergence between the mid-Atlantic ridge and the West coast of Africa on the east. These are the locations of active downwellings and upwellings, respectively. On the eastern side, the situation is slightly more complicated than it is to the west, but nevertheless reveals linear features. Between the mid-Atlantic ridge and the eastern coast of Africa, two elongated zones of upwellings (west of the African margin and beneath the East African rift) bracket smaller upwellings and downwellings beneath Africa. These two upwellings correspond to the major upwellings observed in the flow sections (Fig. 3) and by Forte et al., (2010). The fact that the trace of the downwelling is more continuous than that of the upwelling is well explained by the rheology of hot upwellings, which get more dismantled during their upward route than cold plates do during their descent (e.g. Schubert et al., 2004; Androvandi et al., 2011). In the South Atlantic only, upwellings and downwellings broadly align with great circles, which renders their traces parallel at the scale of the South Atlantic; they approximately combine to form the upwelling and downwelling arms of a $6000-7000 \mathrm{~km}$ wide cylindrical cell that drives South America westward. Zooming out of this domain to the world scale (Fig. 4) reveals that this cylindrical cell in fact belongs to the three dimensional convection pattern that defines the current mantle flow.

\subsection{Relative contributions of upwellings and downwellings:}

The force balance that we have considered so far accounts for both upwellings and downwellings. Although it is consensual that subducting slabs count among the main drivers of plate tectonics, and therefore make the contribution of downwellings in global flow models almost impossible to avoid, the situation is different for upwellings, the nature of which is controversial. In our flow model, seismic velocity anomalies are assumed to exhaustively (besides the uppermost $300 \mathrm{~km}$ ) reveal temperature variations. Some of the seismic velocity variations, however, possibly reveal chemical anomalies, especially in the lower mantle. This uncertainty is not trivial, as it may change the superplume, which drives upwelling in our model, into a dense pile that passively sits on the lower mantle (Gurnis et al., 2000; Ni et al., 2002; 
Ni and Helmberger, 2003; McNamara and Zhong, 2004; Davaille et al., 2005; Samuel and Bercovici, 2006; Deschamps et al., 2007; Garnero and McNamara, 2008; Bull et al., 2009). The South Atlantic domain provides an opportunity to explore whether upwellings actively contribute to driving flow or are only passively advected by mantle flow dominated by downwellings. We isolated the contributions from upwellings and downwellings by alternatively setting the negative and positive seismic velocity anomalies to null in our flow model.

We find that the torque that is exerted by shear tractions from downwellings alone (Fig. 2b, computed as above, but using the "downwellings only" contribution to $\alpha_{\text {ref }}$ from Table 1) can balance the torque exerted by the Andes only with values for $\alpha_{\text {imp }}, \beta$, and $\gamma$ that moderately depart from the standard values (as indicated by the "preferred model", Fig. 2a). In fact, without a contribution from upwellings we find that the balance can only be achieved within a very small domain that requires high seismic velocity to density conversion factor ( $\sim 60 \%$ higher than the value used by Conrad and Behn, 2010), and a rather low viscosity (Fig. 2b). Upwellings alone are also insufficient to make the torques balance, albeit extreme values render it possible (which shows that they contribute positively to drive South America, Fig. 2c). These results suggest that the combination of downwellings and upwellings better achieves the force balance, one reinforcing the other. This can be reconciled by considering that lower-mantle piles (see Figure 3), although dense, nevertheless supply heat to the mantle above them, possibly in the form of plume clusters (e.g., Bull et al., 2009). This advected heat is revealed by the low seismic velocities that are present above the chemical piles, and which drive the convection cell in a way that resembles the flow field we obtained by neglecting the chemical contributions, at least in the topmost parts of the mantle that are most important to our interpretation. However, assigning part of the signal to chemical anomalies would certainly render the upwelling less vigorous and would shift the required values of $\alpha$ and $\gamma$ towards the high range of admissibility.

Because we form solutions from linear combinations of separate driving and resisting stresses, we can isolate the different components to determine their relative contributions (Fig. 5). The sum of all driving components (which is equal and 
opposite to the cumulated resisting components) is given by the sum of the internal tractions and ridge push. These amount to $10.2 \times 10^{12} \mathrm{~N} \mathrm{~m}^{-1}$ on average along the South American trench (including resistance from external traction yields (Fig. 5) a net traction of $8 \times 10^{12} \mathrm{~N} \mathrm{~m}^{-1}$ ). In our preferred model (Figs. $1 \mathrm{~b}$ and $2 \mathrm{a}$ ), ridge push amounts to $39 \%$ of the total driving force, downwellings to $38 \%$, and upwellings to $23 \%$. External tractions are oriented eastward, which effectively decreases the effect of the shear traction from the convecting mantle. That component sums to $18 \%$ of the total force, which requires the orogenic load to oppose the rest of the driving forces, or $82 \%$ of the total force. Although this blend of forces depends on the solution choice, which is non-unique (Fig. 2a,b), our preferred solution is the one that best satisfies independent observations on rheology and plate motion. Thus, our tests suggest that orogenic forces are among the highest contributors to the force balance in general.

\subsection{Latitudinal dependency of the force balance}

The mean force balance supporting the Andes (summarized in equation (4)) can be further decomposed by examining its latitudinal dependency. In order to do so, we integrated the basal shear tractions for our preferred model along individual small circles around the Euler pole from the ridge to the trench (Fig. 1b) and compute the net basal traction per unit trench length along the western margin of South America. To estimate the net westward force arising from the South Atlantic, we included a uniform component of ridge push along the trench, set to $4 \times 10^{12} \mathrm{~N} \mathrm{~m}^{-1}$. The resulting latitudinal dependence (Fig. 5) reveals that the westward-directed net force on the South American plate increases from the northern and southern ends of the trench towards the center. These variations in the net force are due solely to variations in the amplitude of the westward-directed basal tractions associated with both mantle upwelling and downwelling (Fig. 5). Interestingly, this latitudinal variation closely resembles that of the Andean load, with a maximum in the Central Andes. This observation adds to the long list of parameters that exhibit along-strike variations at the plate boundary, including elevation and crustal thickness, but also the geoid (Russo and Silver, 1996), gravity along the trench (Iaffaldano and Bunge, 2008), bulk 
shortening (Kley and Monaldi, 1996), precipitation (Montgomery et al., 2001) and even sediment infill in the trench (Lamb and Davis, 2003).

A straightforward interpretation of the match between Andean load and shear traction would be that forces not only balance on average but also locally, but this statement challenges the idea that plates behave as rigid entities, even large distances from plate boundaries and away from the mountain belts. Instead, we note that the cumulated force exerted by the Andean load north of the central point (at about $23^{\circ} \mathrm{S}$ ) equals the force south of that point, and similarly for the shear traction force (Fig. 5). This balance prevents spinning of the South American plate. A mountain chain that is instead more asymmetrical about its center would induce rotation of the plate (Iaffaldano et al., 2011). In fact, the geoid, but also estimates of slab pull force (Fig. 5, after Wu et al., 2008, derived from Heuret et al., 2005) indicate that the total mass anomaly associated with the Nazca slab is slightly larger to the north of the Central Andes, which drives an integrated shear force on the South American plate that is maximal between $10^{\circ} \mathrm{S}$ and $18^{\circ} \mathrm{S}$, slightly to the north of the central zone. (Note also that slab pull estimates give a mean value of $\sim 4010^{12} \mathrm{~N} \mathrm{~m}^{-1}$, which suggests that only $\sim 10 \%$ of that force converts, via the flowing mantle, into the 10 times smaller shear traction force due to downwellings only, Fig. 5). Conversely, driving shear due to upwelling is more powerful in the central-southern zone. Together, these two components evenly distribute the driving shear tractions between the northern and southern sides of the plate boundary, and are maximized in the center of the cell. If the plate were solely driven by downwellings, convergence would be faster in the North than in the South and a spinning component would add to the motion of South America, or this spinning would be slowed by additional growth of the northern part of the Andes. The absence clockwise spinning of South America and the lack of additional mass in the northern Andes support the above idea that upwellings actively contribute to driving mantle flow.

The broadly cylindrical South Atlantic convection cell, triggered by the joint effects of upwellings and downwellings, is thus seemingly more vigorous in the center than on its edges. This could either result from a dynamic evolution of the system that tends to make convection cells more powerful in their centers, or from a 
coincidental situation of the present-day Earth in which forces balance around a pivotal point in the center of the Nazca trench (where the Andes reach their maximal elevation). Regardless, the observed topographic symmetry of the Andes mountain chain may reflect the presence of both Nazca downwelling and African upwelling as drivers of the stable westward motion of South America.

\section{4) Discussion: South America and Africa over a stationary South Atlantic cell}

The results of our dynamic models provide a framework onto which the behavior of the South Atlantic convection cell and plate tectonics should fall. In the following, we match our model results to first order geological observations of the South Atlantic system, from the Andes to Africa. The geological record can be used to test the plausibility of our model results. Conversely, our results help to interpret some of those observations.

\subsection{Stability of vertical currents in the mantle}

In a mantle reference frame, Africa and South America diverge above a large convection cell (Silver et al., 1998). However, the surface tectonics of these plates do not always align with the geometry of this cell. For instance, a closer examination of the divergence map (Fig. 4) reveals that both the negative divergence (which locates the slab, as viewed from the density field at depth) and the positive divergence (which reveals upwellings) are offset to the east by $1000-1500 \mathrm{~km}$ with respect to the presentday locations of the trench and ridge. Indeed, the Nazca slab dips at shallow angles in the upper mantle and the slab systematically reaches the lower mantle $\sim 1000 \mathrm{~km}$ away from the trench (Espurt et al., 2008; Martinod et al., 2010), i.e. approximately above the slab in the lower mantle (Fig. 4). Similarly, the strip of positive divergence is offset from the present-day location of the ridge and instead aligns with the elongated, "banana-shaped" (Davaille et al., 2005), African superplume, along the Western margin of Africa. In fact, the location of upwelling aligns better with the trace of the -diachronous- location of initial rifting (Fig. 4). This indicates that the presence of long-lasting hotspots (Fig. 1a) controlled the location of the initial 
breakup of the Atlantic (Davaille et al., 2005; Torsvik et al., 2008). It also indicates that the initial alignment of ridges, hotspots and divergence may have become distorted through time.

Since the initial breakup during Early Cretaceous, the Atlantic ridge began a westward journey (see for instance the reconstructions by Torsvik et al., 2010) and drifted away from its initial location above the upwelling. Secondary morpho-tectonic features arise from this drift on the eastern side of the ridge: hotspots in the South Atlantic are located to the East of the ridge (Fig. 1a, Silver and Russo, 1998); the eastern limb of the ridge is more elevated than its western counterpart, possibly as a result of the westward drift of the lithosphere above the mantle upwelling (Doglioni et al., 2003). These observations suggest that the zone of upwelling, if not completely stationary, at least remained in the vicinity of its pre-breakup location. This argues for only a mild control of plate kinematics on the underlying mantle flow. Similarly, on the western side of the cell, the slab-induced negative divergence lies at an intermediate location between the present-day trench location and the location of the trench at the time of initial breakup (Fig. 4). The location of maximum negative divergence with respect to the past location of the trench suggests that the slab became anchored in the lower mantle at $50 \mathrm{Ma}$ and let South America override it afterwards by several hundreds of kilometers. Again, morpho-tectonic features record this migration of the South American plate over a downwelling zone that remains partly- stationary. Evidence for stationarity of downwellings arises from the sedimentary record: Overriding plates are dynamically deflected downward above subducting slabs with a typical wavelength of about $500 \mathrm{~km}$ (Zhong and Gurnis, 1994; Husson, 2006; Liu et al., 2010); these upper plate depressions sequester sediments, which is observed for South America above the Nazca slab (Guillaume et al., 2008; Dávila et al., 2010, Shephard et al., 2010). In Central South America, the pinchout zone and depocenter of the Subandean foreland basin gradually migrate eastward through time (Uba et al., 2011). This suggests that the dynamic deflection migrates eastward, or more accurately that South America migrates to the West relative to the slab and associated dynamic deflection. This is not surprising given that the Nazca slab dips at an uncommonly low angle in the upper mantle, before it enters a more vertical mode of subduction in the lower mantle. Thus, the South American plate likely deflects the Nazca slab into the upper mantle, and only moderately affects 
its location at depth (see e.g., Van Hunen et al., 2003; Espurt et al., 2008; or Martinod et al., 2010)

4.2 Speculations on the dynamic evolution of the South Atlantic system

In light of our model constraints on the dynamics of the South Atlantic and Andes, and the first-order geological observations that they predict, we propose the following scenario, which assigns a primordial role to upwelling beneath Africa. The South Atlantic basin opened ca. $130 \mathrm{Ma}$ after the convection cell was installed, taking advantage of the pre-existing Atlantic hotspots (Fig. 6a). The South Atlantic basin then spread, while no compression is recorded in South America (moderate extension even took place in the late Cretaceous, Sempere et al., 1997). This indicates that the spreading of the Atlantic was accommodated by the retreat of the Nazca slab, leaving free space for South America to migrate westward. Thus, the location of upwelling remained approximately stationary with respect to the deep mantle (e.g. Torsvik et al., 2008), while the downwelling, i.e. the Nazca-Farallon slab, migrated to the west, thereby increasing the size of the South Atlantic cell (Fig. 6b).

The growth of the Andes implies that trench retrograde migration decreased through time, achieving a slower rate than the westward motion of South America itself (Fig. 6b and c). Different hypothesis can be put forward to explain this kinematic change. Mantle stagnation associated with the Bolivian orocline, on the foreside (West) of the long Nazca slab, is one viable solution (Russo and Silver, 1994; Schellart et al., 2007). An alternative option is that at $~ 50$ Ma the subducting slab penetrated and anchored into the lower mantle, thereby resisting slab rollback (e.g. Enns et al., 2005; Billen et al., 2009). Scaling velocities with viscosity provides the explanation: continents drift at rates that scale with the viscosity of the upper mantle (or with the even-lower viscosity of the asthenosphere), which is lower than the viscosity of the lower mantle by one or more orders of magnitude. For a comparable power, strain rates should therefore be up to 100 times slower in the lower mantle. Thus, upwellings and downwellings, once they become well anchored into the lower mantle, become difficult to move laterally, despite ongoing, and occasionally misaligned, flow in the upper mantle. In our example, the South American plate begins to drift relative to its underlying convection cell after $50 \mathrm{Ma}$. This solution 
agrees with the reconstruction of Ren et al. (2007) and the kinematic analysis of Goes et al. (2008), which indicate that the slab penetrated into the lower mantle around 50 Ma. Indeed, Ren et al. (2007) suggest that the strong positive seismic velocity anomaly presently at depths $1000-1450 \mathrm{~km}$ corresponds to the signature of a possibly denser Farallon plate that subducted between 43 and 64 Ma.

Last, this evolution may also benefit from a fluid mechanical consideration: the distance between the upwellings and downwellings that was achieved ca. 50 Ma could correspond to an optimal aspect ratio from which it is difficult to depart. Indeed, the South Atlantic cell initiated with an aspect ratio of $\sim 1$ (i.e., the width of the South American continent over mantle thickness), assuming that subduction bordered South America's western margin and that upwelling aligned with the initial location of the ridge. Presently, the aspect ratio is between 2 and 3 (considering the distance between the strips of positive and negative divergence, which we interpret as the locations of upwellings and downwellings, over mantle thickness). Reconstructions (Fig. 4) indicate that this aspect ratio may have prevailed since $\sim 50 \mathrm{Ma}$, the approximate time since the trench last aligned with maximum convergence, and the slab last anchored into the lower mantle. Theoretical models (e.g. Bunge and Richards, 1996; Bunge et al., 1996; Grigné et al., 2007) show that most significant power is found at degree 6 or lower, which corresponds to an aspect ratio of 2.3 for convecting cells in the mantle. Such simulations give first order insights that interestingly compare to our blurred observations of the convective behavior of the Earth. In particular, the relative stability of the South Atlantic cell after $\sim 50$ Ma may illustrate this dependence, where an aspect ratio of 2-3 may be optimal. Once reached, this "stable" framework for convection persists regardless of the evolution of overriding plates at the surface. Of course, the transient nature of this relative stability becomes obvious when comparing the time span of stability (50 Ma) to the typical time scales of mantle convection. During this short time span, the forces that tend to make the aspect ratio depart form its optimal value likely remained smaller than the restoring forces.

Our hypothesis that a stable convection cell developed beneath the South Atlantic implies that this cell became more vigorous during the most recent period in which it operated at an inferred optimal aspect ratio of 2-3 (Fig. 6c). The westward motion of the South American plate over the stationary cell is a manifestation of that 
increase, forcing flat slabs to subduct beneath the South American plate (Martinod et al., 2010). This setting is misleading in the sense that it may lead to the mistaken impression that plates move regardless of the underlying mantle flow. Instead, this situation must be understood as a transient departure from a one-to-one correspondence between plate tectonics and mantle flow.

At the surface, both the African and South American continents bear evidence of fostered mantle activity from the mid-Tertiary onwards. Although individual tectonic, magmatic and morphologic events may each be explained by local processes, it is their coincidental timing, over such wide domains, that make it necessary to envision a common genetic cause, at the scale of the mantle: an increase in the vigor of mantle convection beneath the South Atlantic. In Africa, widespread development of relief and volcanic provinces occurs at $~ 30 \mathrm{Ma}$ (Burke 1996). The most dramatic illustration is probably the Afar plume (Ebinger and Sleep, 1998), which erupted a LIP flood basalt at $\sim 30 \mathrm{Ma}$ (Hofmann et al., 1997) that was followed by the drift of Arabia from Africa at 25-20 Ma (Coulié et al., 2003). In addition, amplified convection may have uplifted South Africa in particular (Gurnis et al., 2000; Lithgow-Bertelloni and Silver, 1998), and the African continent more generally, around $30 \mathrm{Ma}$, as has been well recorded by river profiles (Roberts and White, 2010). The increased vigor of the South Atlantic cell is compatible with increased spreading rates in the South Atlantic basin between 40 and $10 \mathrm{Ma}$ (Conrad and Lithgow Bertelloni, 2007), faster westward motion of South America (Silver et al., 1998), and contraction in the Andes during the Tertiary (Megard, 1984; Isacks, 1988). Although the precise timing is controversial, Andean building started around $50 \mathrm{Ma}$ and accelerated thereafter (see Barnes and Ehlers, 2009, for a review), leaving the main episode of Andean growth after $30 \mathrm{Ma}$. The coevality of the tectonomagmatic events during the Tertiary in South America and Africa suggests a common genesis.

Comparable reorganization may be occurring the lower mantle as well, but on timescales longer than those that apply for the upper mantle. In this slow lower mantle evolution, the downgoing plate beneath South America helped to sweep together the thermo-dynamical piles, and therefore the upwelling above them, accordingly to model predictions (e.g., Garnero and McNamara, 2008). This flow pattern led to the 
development of the tectono-magmatic provinces of Africa, and to the onset of Andean shortening (Fig. 6c). Shortening of the Andes is centered around the Bolivian orocline, where the trench is most stationary. This in turns explains the comparable latitudinal dependence of elevation, basal drag and slab pull (Fig. 5). An increase in the vigor of convection after 50 Ma may have fueled the motion of South America and built the Andes on the western side, while shaping Africa to the east. Downwellings boosted upwellings, and reciprocally, and did so vigorously enough to build the Andes (Fig. 6d).

\section{5) Conclusions}

Andean building is often considered to result from subduction of the Nazca plate. This implicitly discards the role of basal drag as a primary force, and leaves an empty space to balance the forces at mountainous plate boundaries. The very existence of the Andes reveals that the force exerted by the South American plate on the South American trench is enough to build the Andes. Our model results confirm that this westward-directed force arises from the South Atlantic cell that drags South America sufficiently to balance the resistance offered by the Andean load. Our flow model is calibrated to balance driving and resisting forces at the Nazca-South America plate boundary, including the Andes. Our most plausible model requires a significant contribution of upwellings beneath Africa that drag South America westward. Thus, basal tractions that result from the joint effects of downwellings and upwellings can explain the growth of the Andes. The comparison to North America is tempting, where arguments from seismic anisotropy suggest that mantle flow drives the westward motion of the plate (Bokelmann, 2002; Eaton and Frederiksen, 2007). A similar driving mechanism could thus have caused the growth of the North American Cordillera, before the western boundary changed from subduction to transform (Atwater, 1970). We suggest, in a more general way, that strong mantle flow, driven by both downwellings and upwellings, is needed to explain the elevation of high mountain belts.

Our model reveals an overall consistency within the South Atlantic domain. 
Spatially, along-cell (or latitudinal) dependence of basal drag compares well to the latitudinal variations of the Andean load. This suggests that driving and resisting forces balance locally in addition to on average, which prevents spinning of the South American plate. Thus, the South Atlantic convection cell is most vigorous in its center, where the resistance from the Andean load is also the highest. Reconstructions indicate that this consistency holds through time, although the relationships between tectonics in South America and the dynamics of the South Atlantic have evolved. The geological record on both sides of the South Atlantic is thus a useful tool for exploring mantle dynamics: the tectonic, morphologic, and magmatic events in Africa and South America are tracers of the underlying convection cell. The fact that the South American plate rides the convection cell nearly freely (i.e., leaving upwellings and downwellings undisturbed) suggests that the geometry of mantle flow is driven internally, rather than imposed from above by the plates, because otherwise positive divergence would still align with the mid-Atlantic ridge and negative divergence with the trench. This tectonic mismatch with underlying dynamics must represent transient behavior because mantle convective forces ultimately drive plate motion. How long can this setting prevail? Is the fact that the convection cell is more vigorous in its center than on its edges in fact a general feature of convection? Does the fossilized aspect ratio of the cell correspond to an optimal convection pattern? Such considerations can only be addressed by further joint analysis of mantle flow and geological record.

\section{Acknowledgements:}

We are grateful to Anne Davaille, Jeroen Van Hunen, and Yanick Ricard for their careful and enthusiastic comments. This work was partially supported by NSF grant EAR-0914712 (C.P.C.).

Androvandi, S., Davaille, A., Limare, A., Foucquier, A., Marais, C., 2011. At least three scales of convection in a mantle with strongly temperature-dependent viscosity. Phys. Earth Planet. Int., in press.

Atwater, T., 1970. Implications of plate tectonics for the Cenozoic tectonic evolution 
of western North America. Bull. Geol. Soc. Amer. 81, 3513-3536.

Asumpçao, M., Guarido, M., van der Lee, S., Dourado, J.C., 2011. Upper-mantle seismic anisotropy from SKS splitting in the South American stable platform: A test of asthenospheric flow models beneath the lithosphere, Lithosphere, 3, 173-180, doi:10.1130/L99.1

Barnes, J.B., Ehlers, T.A. 2009. End member models for Andean Plateau uplift, Earth Science Reviews 97, doi:10.1016/j.earscirev.2009.08.003, 117-144.

Becker, T. W., 2006, On the effect of temperature and strain-rate viscosity on global mantle flow, net rotation, and driving forces. Geophys. J. Int. 167, 943-957.

Becker, T.W., and C. Faccenna, 2009. A review of the role of subduction dynamics for regional and global plate motions, in Subduction Zone Geodynamics, ed. by S. Lallemand and F. Funiciello, pp. 3-34, doi:10.1007/978-3-540-87974-9_1, Springer, Berlin.

Bokelmann, G.H.R., 2002. Which forces drive North America? Geology, 30, $1027-$ 1030.

Billen, M. I., 2008. Modeling the Dynamics of Subducting Slabs, Annual Reviews of Earth and Planetary Science 36, 325-356, doi:10.1146/annurev.earth36.031207.124129.

Bull, A.L., A.K. McNamara, and J. Ritsema, 2009. Synthetic tomography of Plume Clusters and Thermochemical Piles, Earth and Planetary Science Letters, 278, 152-162.

Bunge, H.-P., Richards, M.A., Baumgardner, J.R., 1996. The effect of depth dependent viscosity on the planform of mantle convection, Nature, 379, 436438.

Bunge, H.-P., Richards, M.A., 1996, The origin of long-wavelength structure in mantle convection: effects of plate motions and viscosity stratification, Geophys. Res. Lett., 23, 2987-2990.

Burke, K., 1996, The African plate, South African Journal of Geology, 99, 341-409.

Conrad, C.P., S. Bilek, Lithgow-Bertelloni, C., 2004. Great earthquakes and slab pull: interaction between seismic coupling and plate-slab coupling, Earth and Planetary Science Letters, 218, 109-122.

Conrad, C.P., Behn, M.D., 2010. Constraints on lithosphere net rotation and asthenospheric viscosity from global mantle flow models and seismic anisotropy, Geochemistry Geophysics Geosystems, 11, Q05W05, 
doi:10.1029/2009GC002970.

Coulié, Quidelleur, Gillot'P.Y., Courtillot, V., Lefèvre, J.C., Chiesa, S., 2003.

Comparative $\mathrm{K}-\mathrm{Ar}$ and $\mathrm{Ar} / \mathrm{Ar}$ dating of Ethiopian and Yemenite Oligocene volcanism: implications for timing and duration of the Ethiopian traps, Earth and Planetary Science Letters, 206, 477-492.

Davaille, A., Stutzmann, E., Silveira, G., Besse, J., Courtillot, V., 2005. Convective Patterns under the Indo-Atlantic «box», Earth Planet. Sci. Lett 239, 2393-252.

Dávila, F., Lithgow-Bertelloni C., Giménez, M., Tectonic and Mantle Dynamic Controls in the topography and subsidence of the Pampean Plains of Argentina, Geology.

DeMets, C., Gordon, R.G., Argus, D.F., Stein, S., 1994. Effect of recent revisions of the geomagnetic reversal time scale on estimates of current plate motions, Geophys. Res. Lett., 21, 2191-2194. Deschamps, F., Trampert, J., Tackley, P.J., 2007. Thermo-chemical structure of the lower mantle: seismological evidences and consequences for geodynamics, in Superplumes: beyond plate tectonics, D.A. Yuen et al. Eds., Springer, pp. 293-320.

Doglioni C., Carminati E., Bonatti E., 2003. Rift asymmetry and continental uplift. Tectonics, 22, 1024, doi:10.1029/2002TC001459.

Eaton, D.W., Frederiksen, A., 2007. Seismic evidence for convection-driven motion of the North American plate. Nature, 446, 428-431.

Ebinger, C.J., and Sleep, N.H., 1998, Cenozoic magmatism throughout East Africa resulting from impact of a single plume: Nature, 395, 788-791, doi: $10.1038 / 27417$.

Enns, A., Becker, T. W., Schmeling, H., 2005. The dynamics of subduction and trench migration for viscosity stratification. Geophys. J. Int., 160, 761-775.

Espurt, N., Funiciello, F., Martinod, J., Guillaume, B., Regard, V., Faccenna, C., Brusset, S., 2008. Flat subduction dynamics and deformation of the South American plate: Insights from analog modeling. Tectonics, 27, doi:10.1029/2007TC002175.

Forte, A.M., Quéré, S., Moucha R., Simmons, N.A., Grand, S.P., Mitrovica, J.X., Rowley, D.B., 2010, Joint seismic-geodynamic-mineral physical modelling of African geodynamics: A reconciliation of deep-mantle convection with surface geophysical constraints", Earth and Planetary Science Letters.

Funiciello F., Faccenna C., Giardini D., Regenauer-Lieb K., 2003. Dynamics of 
retreating slabs (part 2): insight from 3D laboratory experiments, Journal of Geophysical Research, 108, B4.

Gable, C. W., R. J. O'connell, and B. J. Travis, 1991. Convection in three dimensions with surface plates: Generation of toroidal Flow, J. Geophys. Res., 96, 83918405.

Garfunkel, Z., Anderson, C.A., Schubert, G., 1986. Mantle circulation and the lateral migration of subducted slabs, J. Geoph. Res., 91, 7205-7223.

Garnero, E.J., McNamara, A.K., 2008, Structure and dynamics of Earth's lower mantle, Science, 320, 626-628

Goes S., Capitanio F.A., Morra G., 2008. Evidence of lower-mantle slab penetration phases in plate motions, Nature 451, 981-984.

Grigné, C., Labrosse, S., Tackley, P.J., 2007. Convection under a lid of finite conductivity in wide aspect ratio models: effect of continents on the wavelength of mantle flow. J. Geoph. Res., 112, B08403, doi:10.1029/2006JB004297.

Gripp, A.E. and Gordon, R.G. 2002. Young tracks of hotspots and current plate Velocities. Geophys. J. Int. 150, 321-361.

Guillaume, B., Martinod, J., Husson, L., Roddaz, M., Riquelme, R., 2009. Neogene uplift of central-eastern Patagonia: dynamic response to active spreading-ridge subduction?, Tectonics, 28, doi:10.1029/2008TC002324.

Gurnis, M., Mitrovica, J. X., Ritsema, J., van Heijst, H.-J., 2000. Constraining mantle density structure using geological evidence of surface uplift rates: The case of the African superplume, Geochemistry, Geophysics, Geosystems 1, doi:1999GC000035.

Hager, B.H., and R.J. O’Connell, 1981. A simple global model of plate dynamics and mantle convection. J. Geophys. Res. 86, 4843-4867.

Heuret A., Lallemand, S., 2005. Plate motions, slab dynamics and back-arc deformation. Physics of the Earth and Planetary Interiors 149, 31-51.

Hofmann, C., Courtillot, V., Féraud, G., Rochette, P., Yirgu, G., Ketefo, E., and Pik, R., 1997, Timing of the Ethiopian fl ood basalt event and implications for plume birth and global change: Nature, 389, 838-841, doi: 10.1038/39853.

Husson, L., 2006: Dynamic topography above retreating subduction zones, Geology, doi:10.1130/G22436.1.

Husson, L., Conrad, C.P., Faccenna, C., 2008. Tethyan Closure, Andean Orogeny, 
and Westward Drift of the Pacific Basin, Earth Planet. Sc. Lett., 271, 303-310, doi:10.1016/j.eps1.2008.04.022.

Husson, L., Ricard, Y., 2004. Stress balance above subduction zones - application to the Andes; Earth Planet. Sc. Lett., 222, 1037-1050.

Iaffaldano, G., Husson, L., Bunge, H-P., 2010. Monsoon speeds up Indian plate motion. Earth and Planetary Science Letters, 304, 503-510.

Iaffaldano, G., Bunge, H.P., Dixon, T.H., 2006. Feedback between mountain belt growth and plate convergence. Geology, 34, 893-896. Isacks, B.L. 1988. Uplift of the Central Andean plateau and the bending of the Bolivian Orocline. Journal of Geophysical Research 93, 841-54.

Jolivet, L., Faccenna, C., 2000. Mediterranean extension and the Africa-Eurasia collision, Tectonics, 19, 1095-1106.

Karato and B. Karki, 2001, Origin of lateral variation of seismic wave velocities and density in the deep mantle, J. Geophys. Res., 106, doi:10.1029/2001JB000214.

Kley, J., Monaldi, C.R., 1998. Tectonic shortening and crustal thickness in the Central Andes: How good is the correlation? Geology, 26, 723-726.

Kreemer, C., Holt, W.E., Haines, J., 2003. An integrated global model of present-day plate motions and plate boundary deformation, Geophys. J. Int., 154, 8-34.

Lallemand, S., Heuret, A., Faccenna, C., Funiciello, F., 2008. Subduction dynamics as revealed by trench migration, Tectonics, 27, doi:10.1029/2007TC002212.

Lamb S., Davis, P., 2003. Cenozoic climate change as a possible cause for the rise of the Andes, Nature 425, 792-797, doi:10.1038/nature02049.

Lithgow-Bertelloni, C., Silver, P.G., 1998. Dynamic topography, plate driving forces and the African superswell. Nature 395, 269-272.

Liu, L., Gurnis, M., Seton, M., Saleeby, J., Müller, R.D., Jackson, J.M., 2010. The role of oceanic plateau subduction in the Laramide orogeny, Nature Geoscience 3, 353-357.

McNamara, A.K., Zhong, S., 2004, Thermochemical structures within a spherical mantle: superplumes or piles? J. Geophys. Res. 109, doi:10.1029/2003JB002847.

Martinod, J., Husson, L., Roperch, P., Guillaume, B., Espurt, N., 2010. Horizontal subduction zones, convergence velocity and the building of the Andes, Earth Planet. Sc. Lett., doi:10.1016/j.eps1.2010.09.010

Mégard, F., 1984. The Andean orogenic period and its major structures in central and 
northern Peru, J. Geol. Soc. Lond. 141, 893-900

Montgomery, D.R., Balco, G., Willett, S.D., 2001. Climate, tectonics, and the morphology of the Andes, 29; 579-582; DOI: 10.1130/0091-7613.

Müller R, Sdrolias M, Gaina C, Roest W., 2008. Age, spreading rates, and spreading asymmetry of the world's ocean crust. Geochemistry Geophysics Geosystems, 9, http://dx.doi.org/10.1029/2007GC001743.

Meade, B.J., Conrad, C.P., 2008. Andean growth and the deceleration of South American subduction: Time evolution of a coupled orogen-subduction system, Earth and Planetary Science Letters, 275, 93-101.

Naliboff, J.B., Conrad, C.P., Lithgow-Bertelloni, C., 2009. Modification of the Lithospheric Stress Field by Lateral Variations in Plate-Mantle Coupling, Geophysical Research Letters, 36, doi:10.1029/2009GL040484.

Ni, S. Tan, E., Gurnis, M., Helmberger, D., 2002, Sharp sides to the African superplume, Science 296, 1850-1852.

Ni, S., Helmberger, D., 2003, Seismological constraints on the South African superplume: could be the oldest distinct structure on Earth, Earth Planet. Sci. Lett. 206, 119 - 131.

Parsons, B., Richter, F.M., 1980. A relation between the driving force and geoid anomaly associated with mid-ocean ridges, Earth Planet. Sci. Lett., 51, 445450.

Ren, Y., Stutzmann, E., Van der Hilst, R.D., Besse, J., 2007. Understanding seismic heterogeneities in the lower mantle beneath the Americas from seismic tomography and plate tectonic history, Journal of Geophysical Research, 112, doi:10.1029/2005JB004154.

Ricard, Y., and C. Vigny, 1989. Mantle dynamics with induced plate-tectonics, J. Geo- phys. Res., 94, 17543-17559.

Ricard, Y., C. Doglioni, and R. Sabadini, 1991. Differential rotation between lithosphere and mantle: A consequence of lateral mantle viscosity variations, J. Geophys. Res., 96, 8407-8415.

Richardson, R.M., 1992. Ridge forces, absolute plate motion, and the intraplate stress field, J. Geophys. Res., 97, 11,739-11,748.

Ritsema, J., van Heijst, H.J., Woodhouse, J.H., 2004. Global transition zone tomography, J. Geophys. Res, 109, 10.1029/2003JB002610.

Roberts, G. and White, N. J., 2010. Estimating Uplift Rate Histories from River 
Profiles using African Examples. Journal of Geophysical Research-Solid Earth 115.

Ruff L., Kanamori, H., 1980. Seismicity and the subduction process. Phys. Earth Planet. Inter. 23, 240-252.

Russo, R.M., Silver, P.G., 1996. Cordillera formation, mantle dynamics, and the Wilson cycle, Geology 24, 511-514, doi:10.1130/0091-7613.

Samuel, H., Bercovici, D., 2006, Oscillating and stagnating plumes in the Earth's lower mantle, Earth Planet. Sci. Lett., 248, 90-105.

Schellart, W.P., Freeman, J. Stegman, D.R., Moresi, L., May, D., 2007. Evolution and diversity of subduction zones controlled by slab width. Nature 446, 308-311, doi:10.1038/nature05615.

Schubert, G., Masters, G., Olson, P., Tackley, P., 2004, Superplumes or plume clusters?, Physics of the Earth and Planetary Interiors 146, 147-162.

Sempere, T., Butler, R.F., Richards, D.R., Marshall, L.G., Sharp, W., Swisher III, C.C., 1997. Stratigraphy and chronology of Late Cretaceous-Early Paleogene strata in Bolivia and northwest Argentina. Geological Society of America Bulletin 109, 709-727.

Shephard, G.E., Müller, R.D., Liu, L., Gurnis, M., 2010. Miocene Amazon River drainage reversal driven by plate-mantle dynamics, Nature Geoscience, 3, 870875, doi:10.1038/ngeo1017.

Silver, P., Russo, R.M., Lithgow-Bertelloni, C., 1998. Coupling of South American and African plate motion and plate deformation, Science 279, 60-63.

Solomon, S.C., and N.H. Sleep, 1974. Some simple physical models of absolute plate motions. J. Geophys. Res. 79, 2557-2567.

Stadler, G., M. Gurnis, C. Burstedde, L. C. Wilcox, L. Alisic, and O. Ghattas, 2010. The dynamics of plate tectonics and mantle flow: From local to global scales. Science, 329, 1033-1038.

Tan E., Choi, E., Thoutireddy, P., Gurnis, M., Aivazis, M., 2006. GeoFramework: Coupling multiple models of mantle convection within a computational framework, Geochem., Geophys., Geosyst. 7, Q06001, doi:10.1029/2005GC001155.

Torsvik, T.H., Steinberger, B., Cocks, L.R.M., Burke, K., 2008. Longitude: Linking Earth's ancient surface to its deep interior. Earth Planet Science Letters 276, 273-282. 
Torsvik ,T.H., Rousse, S., Labails, C., Smethurst, M.A. 2009. A new scheme for the opening of the South Atlantic Ocean and the dissection of an Aptian salt basin. Geophysical Journal International 117, 1315-1333.

Torsvik, T. H., B. Steinberger, M. Gurnis, and C. Gaina, 2010. Plate tectonics and net lithosphere rotation over the past $150 \mathrm{My}$, Earth and Planetary Sciences Letters, 291, 106-112.

Turcotte, D., Schubert, G., 1982, Geodynamics, Wiley, 450 p.

Uba, C.E., Kley, J., Strecker, M., Schmitt, A., 2009. Unsteady evolution of the Bolivian Subandean thrust belt: the role of enhanced erosion and clastic wedge progradation. Earth and Planetary Science Letters 281, 134-146.

van Hunen, J.,, van den Berg, A.P., Vlaar, N.J., 2004. Various mechanisms to induce present-day shallow flat subduction and implications for the younger Earth: a numerical parameter study. Physics of the Earth and Planetary Interiors 146, 179-194.

Wu, B., C.P. Conrad, and A. Heuret, C. Lithgow-Bertelloni, Lallemand, S., 2008. Reconciling strong slab pull and weak plate bending: The plate motion constraint on the strength of mantle slabs, Earth and Planetary Science Letters, 272, 412-421.

Zhong, S., 2001. Role of ocean-continent contrast and continental keels on plate motion, net rotation of the lithosphere, and the geoid, J. Geophys. Res. 106, 703-712.

Zhong, S.J., Zuber, M.T., Moresi, L., Gurnis, M., 2000. Role of temperaturedependent viscosity and surface plates in spherical shell models of mantle convection, J. Geophys. Res., 105, 11063-11082.

Zhong, S.J., Gurnis, M., 1994. Controls on trench topography from dynamic models of subducted slabs, J. Geophys. Res. 99, 15683-15695.

Figure 1: a) Tectonic setting of the South Atlantic and Andean domain. Vectors indicate the surface velocity field in the HS3-NUVEL-1A (burgundy, Gripp and Gordon, 2002) and in the NNR-NUVEL1A (green, deMets et al., 1994) reference frames, which we show as end members for plate motion. Yellow stars and circles show the location of hotspots from the exhaustive collection of Anderson (mantleplumes.org) and from that of Courtillot et al. (2003), respectively. b) Vectors 
give the net shear traction at the base of the lithosphere (color scale saturates at 3 $\mathrm{MPa}$ ), computed from global mantle flow model driven by density heterogeneities as inferred from seismic tomography beneath a moving lithosphere (see text for details). Green curves are small circles corresponding to the internal (mantle flow) shear traction torque whose Euler pole is indicated by a green star. They locate the profiles shown Figure 3. Colored dots along the Nazca trench give the integral shear force along the small circles defined by this Euler pole.

Figure 2: Compatible combinations of $\alpha_{\mathrm{imp}}, \beta$, and $\gamma$ that solve equation (4), for downwellings and upwellings (a), downwellings only (b), and upwellings only (c). Black star is the preferred combination that corresponds to standard values for mantle viscosity $(\beta=0.5)$, seismic velocity to density conversion factor $(\gamma=1.13$, corresponding to $0.17 \mathrm{~g} \mathrm{~cm}^{-3} \mathrm{~km}^{-1} \mathrm{~s}$ ) and net rotation ( $\alpha_{\mathrm{imp}}=0.2$, corresponding to $\alpha_{\mathrm{tot}}=0.33$ times that of HS3). White contours correspond to $\alpha_{\mathrm{tot}}$. Pink domain indicates that there is no value for $\beta$ that solves for equation (4). Black boxes indicate most plausible fields, with boundaries as defined in the text.

Figure 3: Cross sections through the mantle density model (color-coded) and flow model (arrows) derived from seismic tomography and associated with the preferred model (star in Fig. 2a), across the Nazca, South American, and African plates (from North to South, location of the profiles are shown as green small-circles in Fig. 1b). Gray areas denote the lithosphere. Pink line is the upper mantle / lower mantle boundary. The blue domains around $30^{\circ}$ to $40^{\circ}$ outline the downwelling, subducting slab; the red units near the core-mantle boundary, around $90^{\circ}$ to $140^{\circ}$, outline the thermo-chemical piles.

Figure 4: Horizontal divergence of the normalized shear tractions. -0.15 and 0.15 contours (yellow lines) outline the zones of relevant divergence. Top: world map; bottom: South Atlantic domain. Green curves show the migration of the Nazca- 
Farallon trench in an absolute reference frame; green dashed curve shows the absolute location of breakup of the South Atlantic ocean (after Müller et al., 2008).

Figure 5: Latitudinal dependency of the force balance along the Nazca trench. Internal traction (green diamonds) shows the cumulated shear stresses beneath the South American plate, including downwellings (downward triangles) and upwellings (upward triangles). External traction (purple right triangles) corresponds to the shear force due to plate motion over the mantle. Andean load refers to the sum of the buoyancy and viscous forces (grey domain, Husson et al., 2008). Ridge push (dotted line) is uniformly set to $4 \times 10^{12} \mathrm{~N} \mathrm{~m}^{-1}$. Cumulative shear traction is the sum of all components (magenta dashed). Tractions are integrated from the ridge to the trench (see text for details).

Figure 6: Cartoon showing the evolution of the South Atlantic from Pangea breakup to present-day. 
- Upwellings and downwellings form a cylindrical cell in the South Atlantic.

- Both upwelling and downwelling forces are required to form the Andes.

- Convection cell transiently remains stationary with respect to plate tectonics.

- Convection vigor increased at $230-50 \mathrm{Ma}$.

- It reshaped Africa and South America. 
Click here to download Figure: fig1_maps.pdf
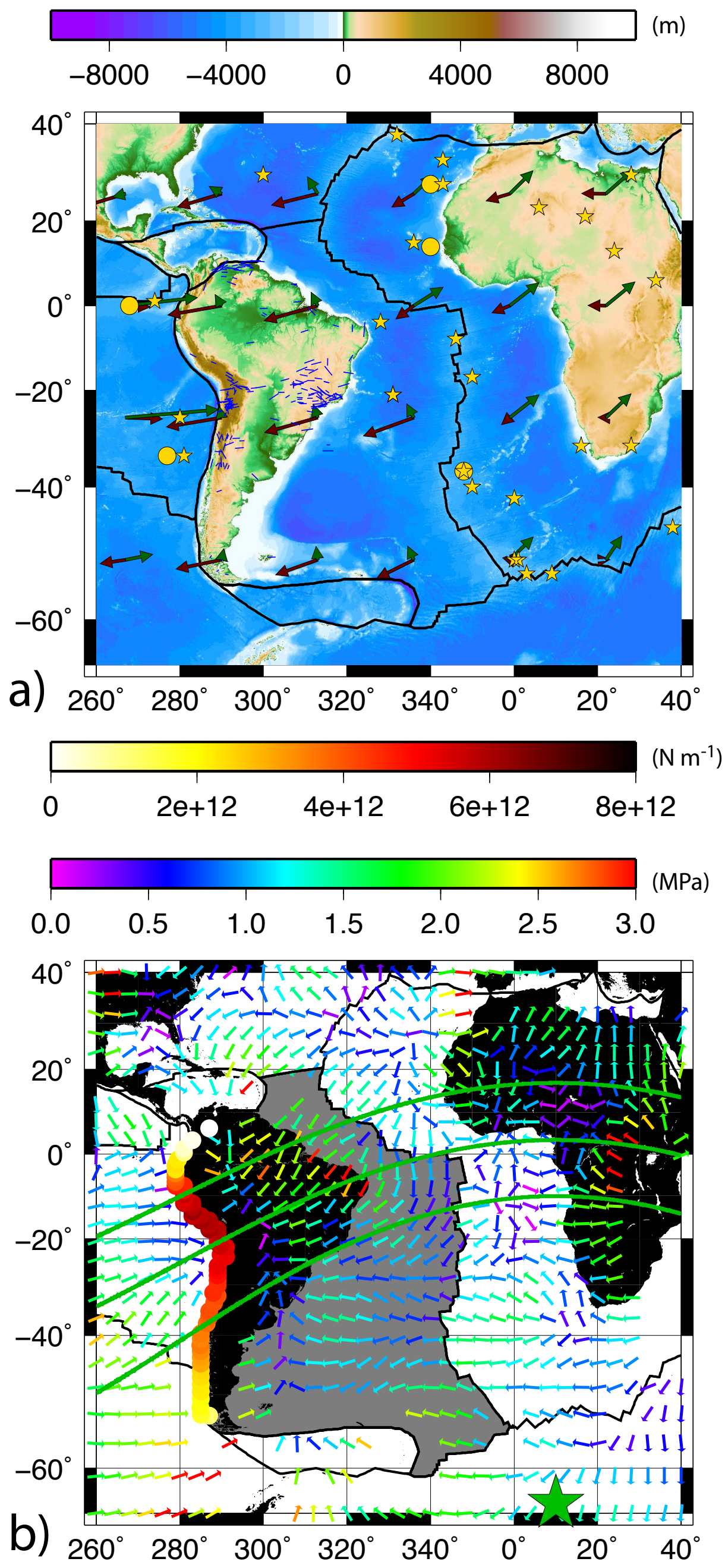


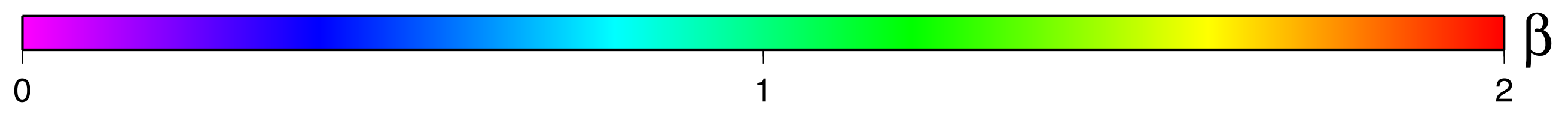

$\begin{array}{ll}\text { a) upwellings + downwellings } & \text { b) downwellings only }\end{array}$

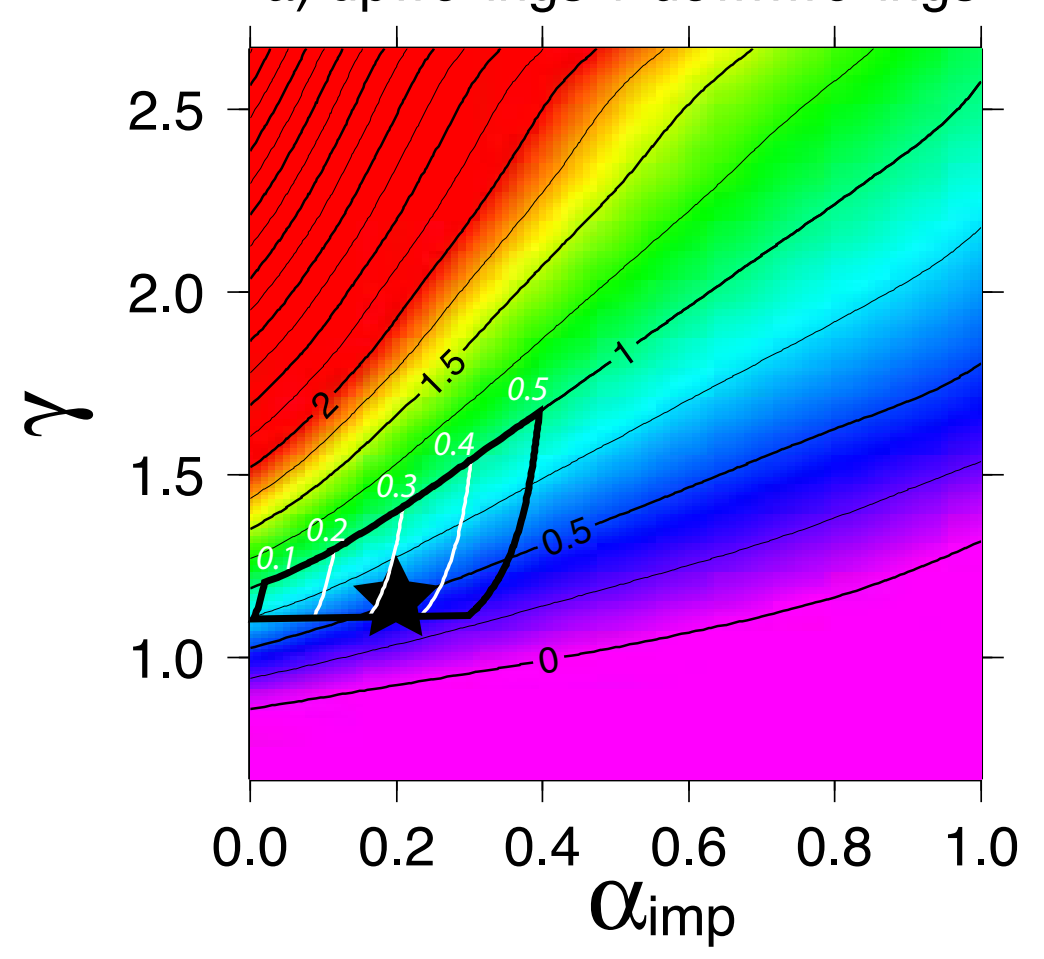

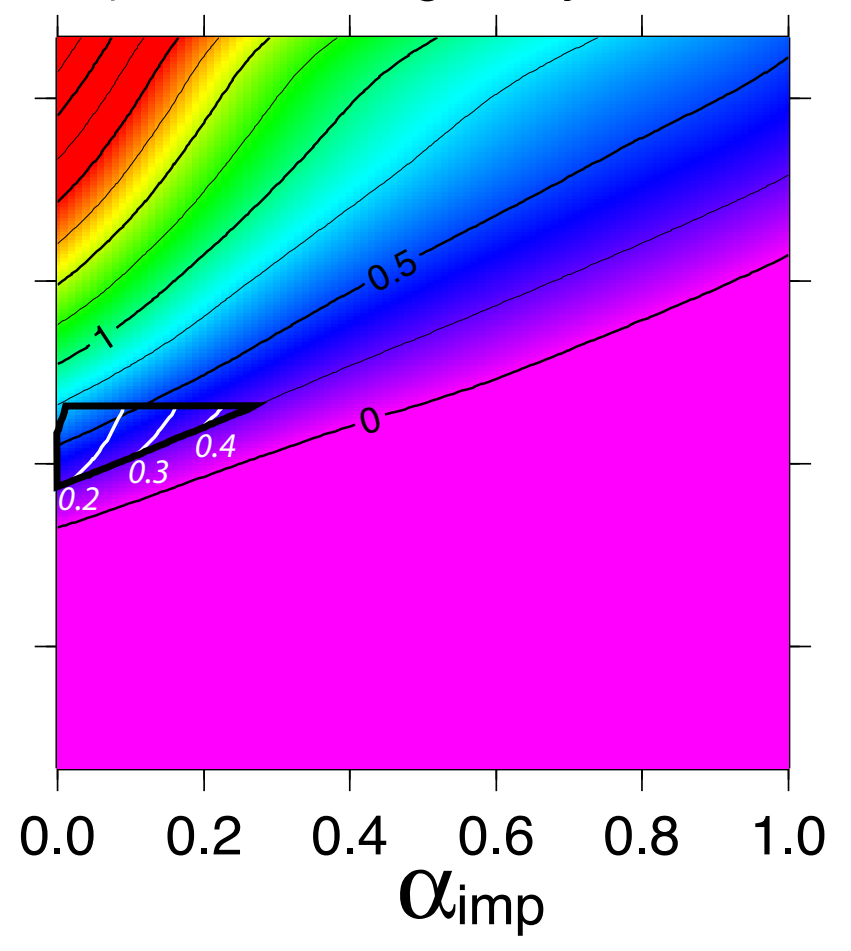

c) upwellings only

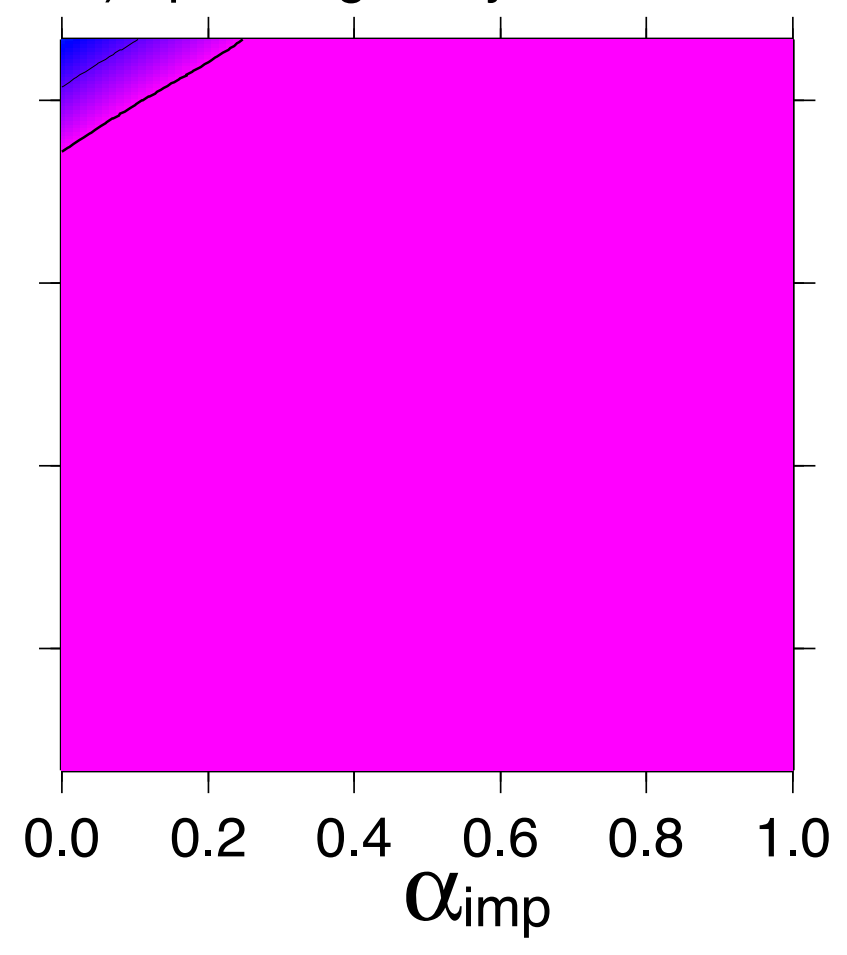




\section{Figure3}

$\begin{array}{lll}60^{\circ} & 70^{\circ} \quad 80^{\circ}\end{array}$

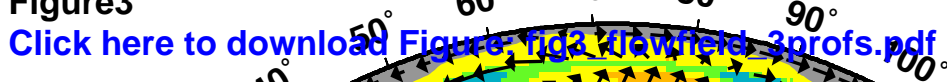

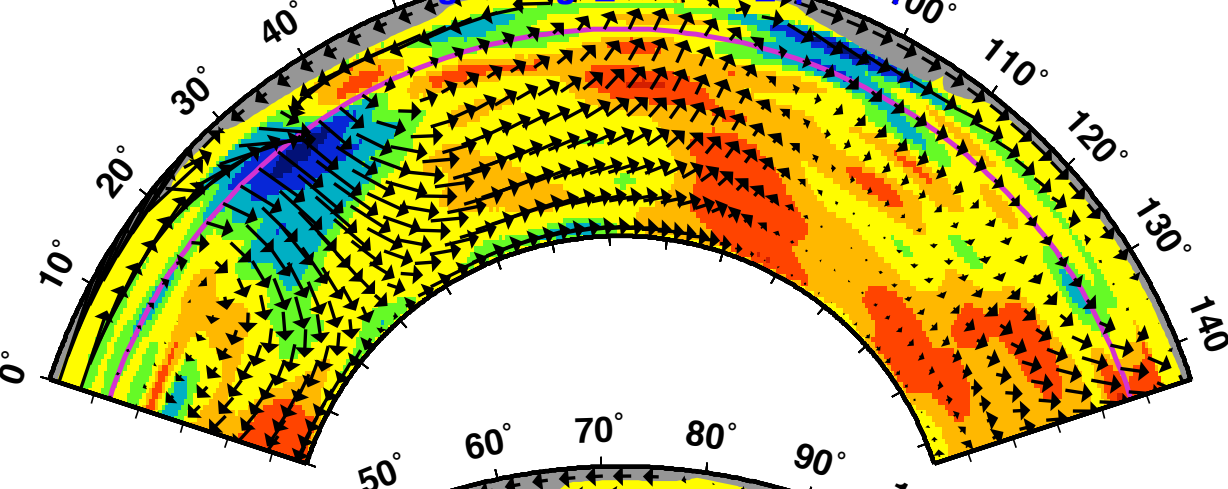

90

100 .
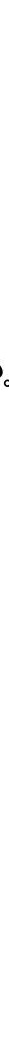

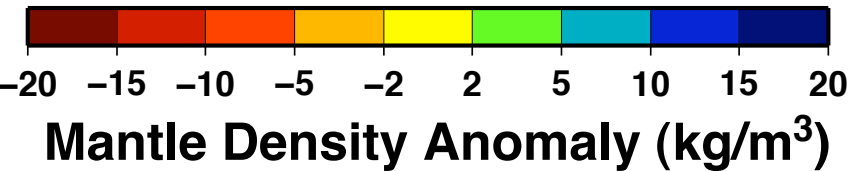


force $\left(x 10^{12} \mathrm{~N} \mathrm{~m}^{-1}\right)$

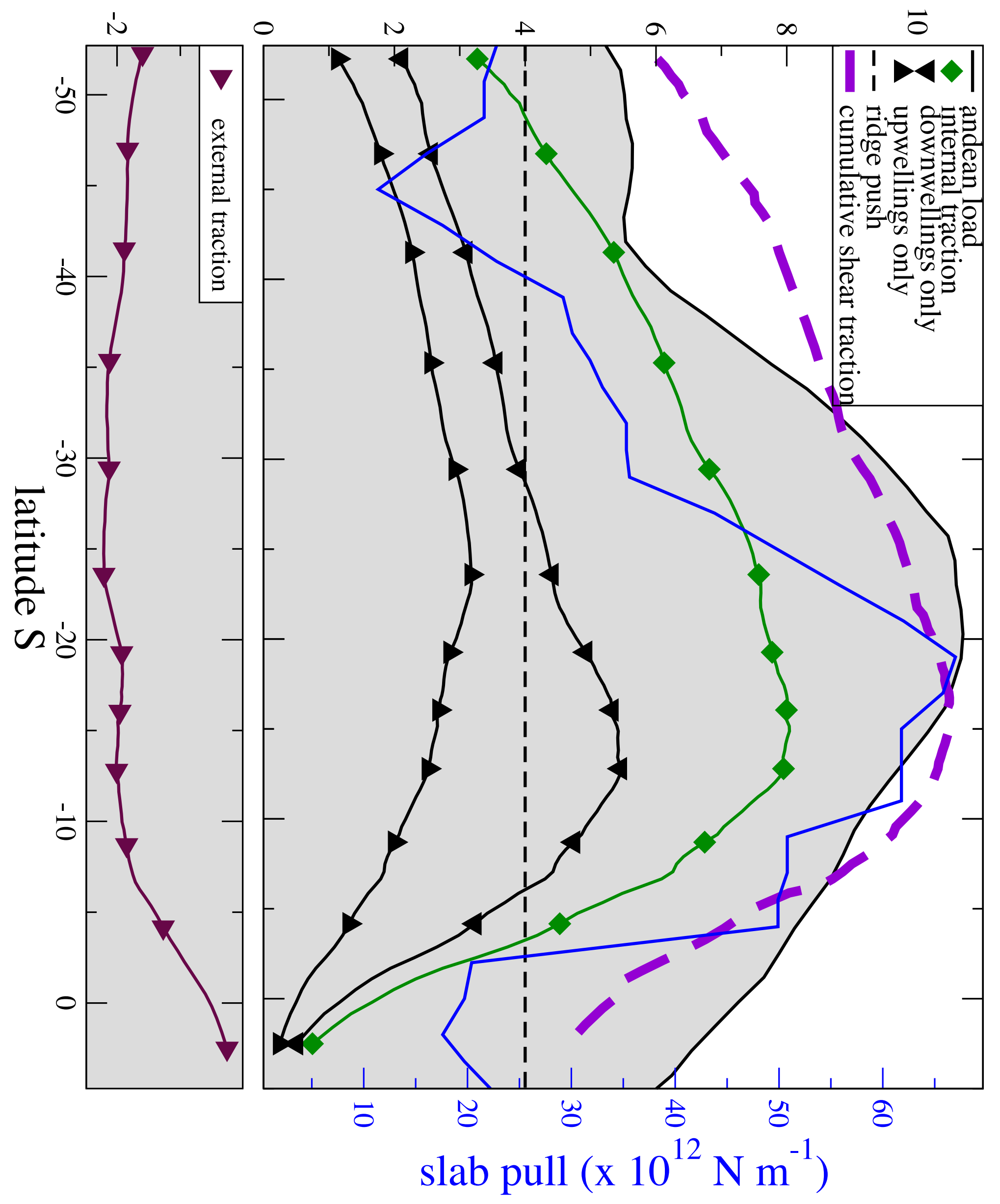




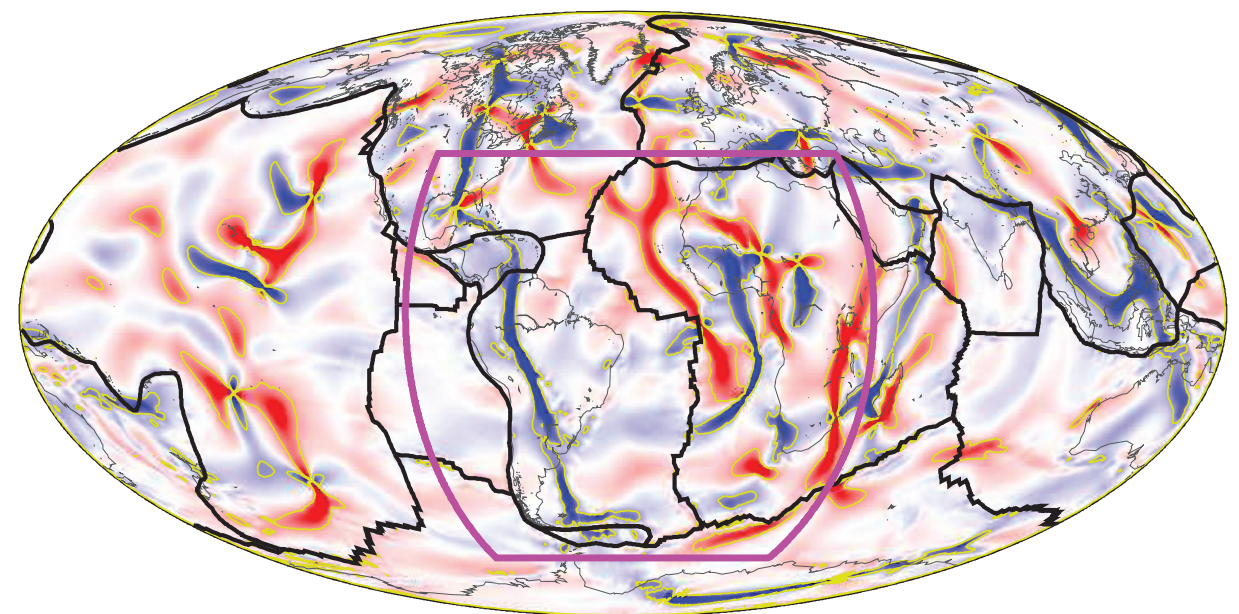

$\operatorname{div}$

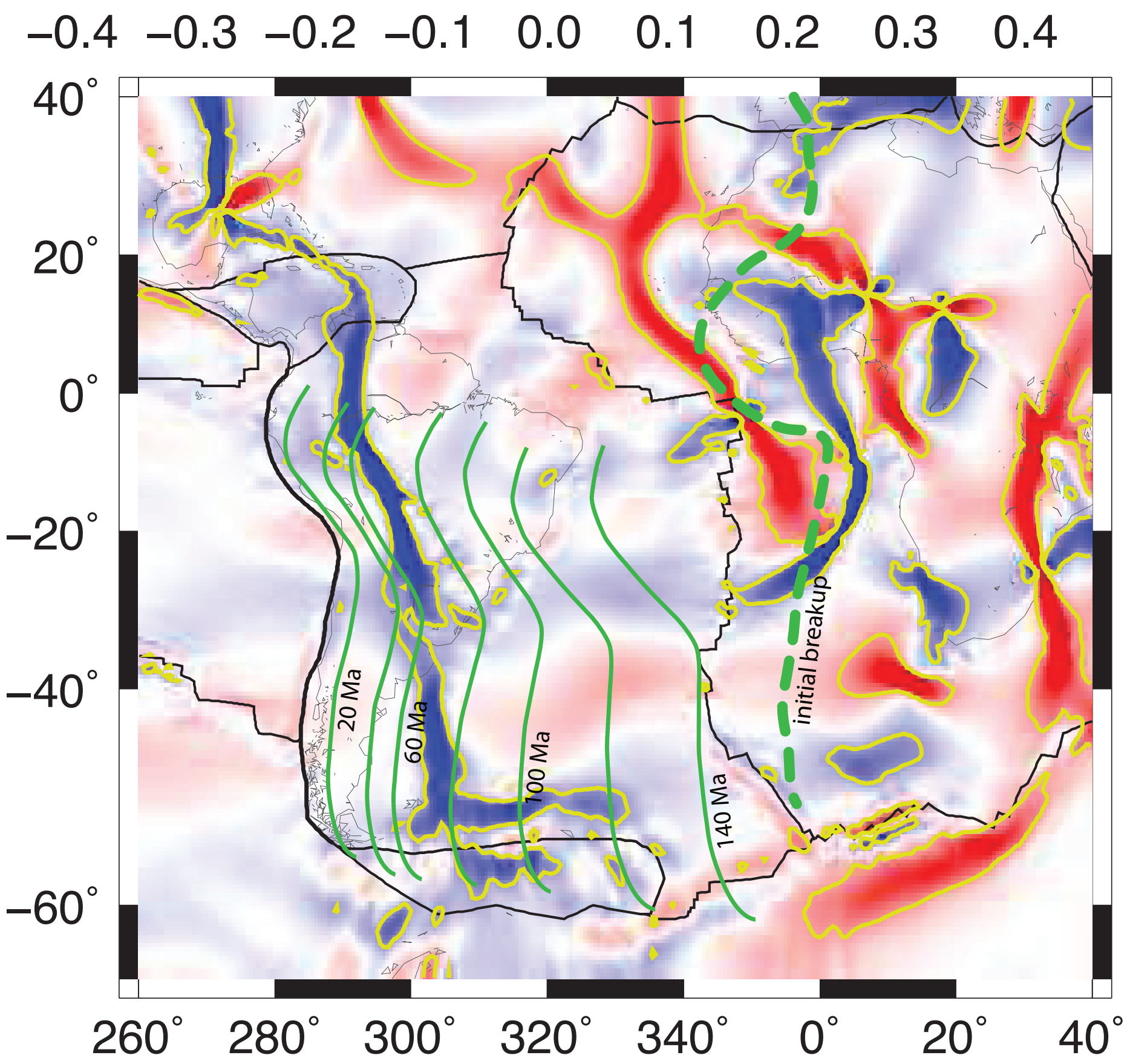




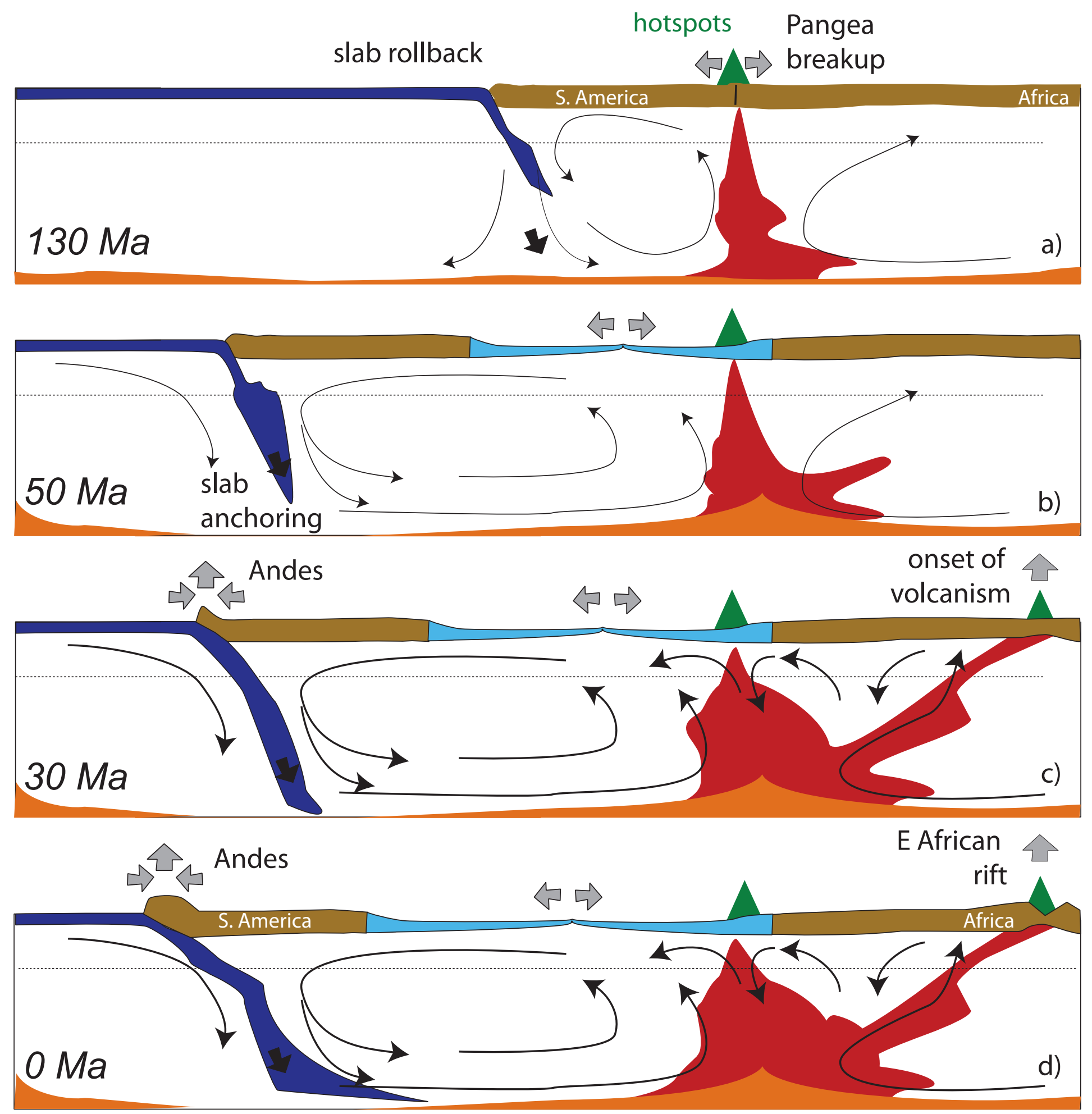




\begin{tabular}{|l|c|c|c|c|c|}
\cline { 2 - 6 } \multicolumn{1}{c|}{} & $\begin{array}{c}\text { Boundary } \\
\text { for Net } \\
\text { Rotation } \\
\text { Measure }\end{array}$ & $\begin{array}{c}\text { Net } \\
\text { Rotation } \\
\text { Pole } \\
\text { (Lat, Lon) }\end{array}$ & $\begin{array}{c}\text { Net } \\
\text { Rotation } \\
\text { Rate } \omega \\
(\% / M y r)\end{array}$ & $\begin{array}{c}\text { Maximum } \\
\text { Rotation } \\
\text { Amplitude } \\
(\mathrm{mm} / \mathrm{yr})\end{array}$ & $\begin{array}{c}\text { Fraction of } \\
\text { HS3 Net } \\
\text { Rotation }\end{array}$ \\
\begin{tabular}{|l} 
Density-Driven Flows \\
$(\boldsymbol{\beta}=\mathbf{1 . 0 ,} \boldsymbol{\gamma}=\mathbf{1 . 0})$
\end{tabular} & CMB & $(-66.6,71.0)$ & -0.0219 & -2.436 & 0.050 \\
\hline $\begin{array}{l}\text { Upwellings and } \\
\text { Downwellings }\end{array}$ & CMB & $(-66.4,54.8)$ & -0.0126 & -1.404 & 0.029 \\
\hline Downwellings Only & CMB & $(-64.3,93.3)$ & -0.0094 & -1.043 & 0.021 \\
\hline Upwellings Only & & & & & \\
\hline Plate-Driven Flows & CMB & $(-8.9,130.8)$ & -0.0092 & -1.025 & 0.021 \\
\hline NNR Plate Motions & Surface & $(-56.0,70.0)$ & 0.4389 & 48.805 & 1.0 \\
\hline HS3 Plate Motions & & & & & \\
\hline
\end{tabular}

Table 1. Net rotation characteristics (pole location and rotation rates) of the different flow models that are combined to form the total flow solutions. All density-driven flows are beneath a non-rotating rigid lid; shown is the non-zero net rotation that occurs on the core-mantle boundary (CMB). For plate-driven flows, shown is the net rotation on the $\mathrm{CMB}$ for a flow field driven by imposed no-net-rotation (NNR) surface plate motions. All CMB net rotation rates, which contribute to $\alpha_{\text {ref }}$ in equation (1), are given as a fraction of the HS3 net rotation amplitude (for density-driven flows, values are given for $\beta=1.0$ and $\gamma=1.0$ ). 